\title{
School Aggression: Effects of classroom environment, attitude to authority and social reputation among peers
}

\author{
Estefanía Estévez, Cándido J. Inglés and $\mathrm{M}^{\mathrm{a}}$ Carmen Martínez-Monteagudo \\ Universidad Miguel Hernández de Elche (Spain)
}

Several researches have demonstrated the relationship between social environment in the classroom and involvement in aggressive behaviours at school. Little is known, however, about the mechanisms explaining this link and intermediating factors that may be affecting such association. In this line, the aim of the present study was to examine the role played by attitude to authority and social reputation among peers; in other words, we analysed the influence of classroom environment, considering interactions with both teachers and other classmates, on aggressive behaviours at school, and treating attitude to authority and social reputation among peers as intermediating variables. The sample was composed of 1319 adolescents, ranging in age from 11 to 16 years (47\% male). Participants were drawn from seven state secondary schools in Valencia (Spain). A structural equation model was tested using the EQS Program in order to analyse interactions among variables. Results revealed an indirect association between classroom environment and aggression through attitude to authority and social reputation, both of which were, in turn, directly related to school aggression. Practical implications of these findings are discussed in relation to school policies, teacher education programs and intervention practices with students in the classroom.

Key words: School, aggression, classroom environment, attitude to authority, social reputation.

Agresión escolar: Efectos del ambiente del aula, la actitud hacia la autoridad y la reputación social entre los iguales. Numerosas investigaciones han mostrado la relación existente entre el ambiente social del aula y la implicación en conductas agresivas en la escuela. Poco se sabe, sin embargo, sobre los mecanismos explicativos de esta asociación y los factores intermedios que pueden estar afectando dicha relación. En esta línea, el objetivo del presente estudio fue examinar el rol desempeñado por la actitud hacia la autoridad y la reputación social entre los iguales; en otras palabras, se analizó la influencia del ambiente en el aula, considerando tanto las interacciones con el profesorado como con otros alumnos, en el comportamiento agresivo en la escuela, y tratando la actitud hacia la autoridad y la reputación social entre los iguales como variables intermedias. La muestra se compuso de 1319 adolescentes con edades comprendidas entre los 11 y los 16 años (47\% chicos). Los participantes pertenecían a siete escuelas secundarias públicas de Valencia (España). Se calculó un modelo de ecuaciones estructurales con el Programa EQS con el objeto de analizar las interacciones entre las variables. Los resultados mostraron una asociación indirecta entre el ambiente en el aula y la agresión a través de la actitud hacia la autoridad y la reputación social, estando ambas, a su vez, directamente relacionadas con la agresión escolar. Se discuten las implicaciones prácticas de estos resultados en relación con políticas escolares, programas de educación del profesorado y prácticas de intervención en el aula con estudiantes.

Palabras clave: escuela, agresión, clima del aula, actitud hacia la autoridad, reputación social.

Correspondence: Estefanía Estévez López. Departamento de Psicología de la Salud. Facultad de Ciencias Sociosanitarias. Universidad Miguel Hernández de Elche. Avda. de la Universidad, s/n. C.P. 03202. Elche, Alicante (España). E-mail: eestevez@umh.es 
In the previous decades, aggressive behaviours at school have become an important concern for teachers, parents and the society in general, due to the negative consequences these behaviours exert on the teaching-learning process, the psychological adjustment of aggressors and victims, as well as on the quality of social interactions in the educational settings (Estévez, Musitu \& Herrero, 2005; Hunter, Mora-Merchán \& Ortega, 2004; Smith \& Brain, 2000; Torregrosa et al., 2012). Several researchers have shown the negative influence of school aggression on the classroom environment, and correspondingly how that negative environment affects students' behavioural adjustment at school and increases their involvement in misbehaviours and aggressive activities in the classroom (Carrasco \& Trianes, 2010; Lawrence \& Green, 2005; Samdal, 1998; Sprange et al., 2001). In the attempt of clarifying the most important concepts in this study, it must be remarked that, on the one hand, with the term aggression we refer here to a behavioural pattern involving direct or manifest acts of violence, as well as indirect or relational aggression towards others (Little, Henrich, Jones \& Hawley, 2003); on the other hand, classroom environment entails the social construction of interactions and perceptions that students develop about the school and the classroom setting (Trickett, Leone, Fink \& Braaten, 1993). Therefore, it is a reflection of positive or negative feelings about the social climate of the context in which they all interact (Peterson \& Skiba, 2000).

A positive classroom environment exists when students feel comfortable, valued and socially accepted in a climate based on support, mutual respect and trust (Moos, 1974). More concretely, the two principal elements that constitute this positive environment at school are (Yoneyama \& Rigby, 2006): (1) support and respect from teachers, and (2) enjoyment of relationships with peers in the class. Furthermore, prior research has shown that having positive interactions with the teacher inhibits development of misbehaviours at school, whilst a negative teacher-student relation adversely affect students' psychosocial adjustment and may contribute to escalating of aggression in schools (Blankemeyer, Flannery \& Vazsonyi, 2002; Reinke \& Herman, 2002). Likewise, children and adolescents develop important -sometimes the firstsocial interactions with others of the same age in the school context, and these peer relations have a significant influence on their emotions and behaviours: relations with peers may provide beneficial opportunities to learn socially accepted values and attitudes, or to acquire interpersonal skills such as ability to handle conflict (Hartup, 1996; Inglés, 2009; Laursen, 1995). However, they also may constitute a crucial influence on participation in risk behaviours and involvement in antisocial and aggressive acts (Dishion, 2000; Barnow, Lucht \& Freyberger, 2005).

But what are the factors explaining the link between quality of interactions with teachers and classmates, on the one hand, and aggression at school, on the other? The direct association between these two aspects of life at school, as aforementioned, 
has been well documented. Thus, several studies show how perception of peers in the classroom as friends or colleagues and a supportive relationship with teachers are both significantly related to adolescent psychosocial and behavioural adjustment and negatively to aggressive behaviour (Andreou, 2000; Demaray, Malecki, Davidson, Hogdson \& Rebus, 2005; Estévez, Herrero, Martínez \& Musitu, 2006; Estévez, Murgui \& Musitu, 2008). However, research on the mechanisms explaining how that relationship is established for some adolescents is much scanter. Understanding the process by which both factors - classroom environment and students' aggression- are connected, merits further investigation from our point of view, since the clarification of these matters would have a clear contribution in ameliorating problems of social rejection, victimization and, ultimately, aggression in schools. In the present study, the role played by two crucial factors in adolescent lifespan, namely attitude to authority and social reputation among peers, are examined.

Some previous research suggests that school experience shapes the orientation towards institutional and formal authorities (Molpeceres, Lucas \& Pons, 2000). Students feeling comfortable and liked in this setting are more likely to consider the school as a useful learning context. The purpose of that learning context may be viewed by the student as a construct that may help them build a successful future, and as a valued scenario where it is possible to share enriching experiences with others. Such students, as a consequence of this, will normally express positive attitudes towards teachers and the school and will not normally exhibit behavioural problems (Jack et al., 1996; Molpeceres et al., 2000; Samdal, 1998). In contrast, negative experiences at school based on unhealthy interactions with teachers and classmates damage children's and adolescents' academic and social potential (Moote \& Wodarski, 1997; Murray and Murray, 2004), and fosters in them feelings of insecurity and emptiness as a consequence of the deep lack of social capital they experience (Barry, 2006).

Emler and Reicher (2005) and Emler (2009) suggest that many behavioural problems in adolescence are the result of disappointment or lack of trust in authority figures. Moreover, those authors state that this process usually starts at school when children increase contact with other peers, in many cases beyond the supervision of adults. In that new social environment, the students are exposed to both positive and negative acts on the part of others -the classmates-, and in the second case to the subsequent protection from school authorities. As children approach adolescence, they start questioning those formal authorities as they realise that the protection they offer is not perfect and, thus, for some, the subsequent establishment and maintenance of a particular social reputation based on strength, braveness and tough emotions is essential as an alternative that guarantees self-protection. This search for social recognition is, therefore, closely related in many occasions to a strong desire for popularity, leadership and power (Rodríguez, 2004), which is in turn a risk factor for aggressive behaviour 
(Buelga, Musitu, Murgui \& Pons, 2008; Carroll, Hatti, Durkin \& Houghton, 1999; Emler \& Reicher, 2005).

Both factors, namely attitude to school and social reputation among peers, seem to be closely linked to aggressive behaviour in this period of life. In other words, it has been documented that students who display negative attitudes to formal figures and institutions, such as teachers and the school context (Emler \& Reicher, 1995; Hoge, Andrews \& Lescheid, 1996; Loeber, 1996), and who search for social recognition as non-conforming individuals (Buelga et al., 2008; Carroll, Green, Houghton \& Wood, 2003; Emler \& Reicher, 2005), are more likely to develop aggressive behaviours against others. Research hitherto however, has focused on studying their independent contribution in the explanation of adolescent behaviour, whilst the jointly analysing of these factors to enhance our understanding of the link between quality of classroom environment and students' involvement in aggressive behaviours at school has yet to be explored. The current research provides a comprehensive consideration of these variables with the aim of achieving a more accurate picture of the interrelation of factors explaining school aggression.

The main objective of the present study was, therefore, to analyse the role played by attitude to school and social reputation among peers in the link between classroom environment and aggression at school. In other words, we aimed to examine the influence of classroom environment on aggressive behaviour at school, treating attitude to school and social reputation among peers as intermediating variables in this relationship. Classroom environment was defined here by the two dimensions distinguished by Moos, Moos and Trickett (1989) and Yoneyama and Rigby (2006): perception of a supportive relation with teachers, and perception of friendships and affiliation among peers in the classroom. The contribution of these two latter factors was separately analysed. Thus, the specific objectives of the study were: (1) to analyse the direct association between social environment in the classroom (teacher support and peer affiliation) and school aggression, and (2) to analyse the indirect relationship between classroom environment and school aggression through the influence of the former on students' attitude to authority and of this latter on social reputation. Taking into account previous findings, we hypothesised that perception of a social environment based on judgements of interactions with teachers and classmates as aforementioned, would influence adolescents' attitude to authority, which in turn would be related to the search of a particular social reputation; it was expected that attitude to authority and nonconforming social reputation contributed to school aggression. The theoretical model proposed is shown in figure 1. 
Figure 1. Theoretical model proposed to analyse the direct and indirect effects of the two dimensions of school environment on school aggression through attitude to authority and social reputation

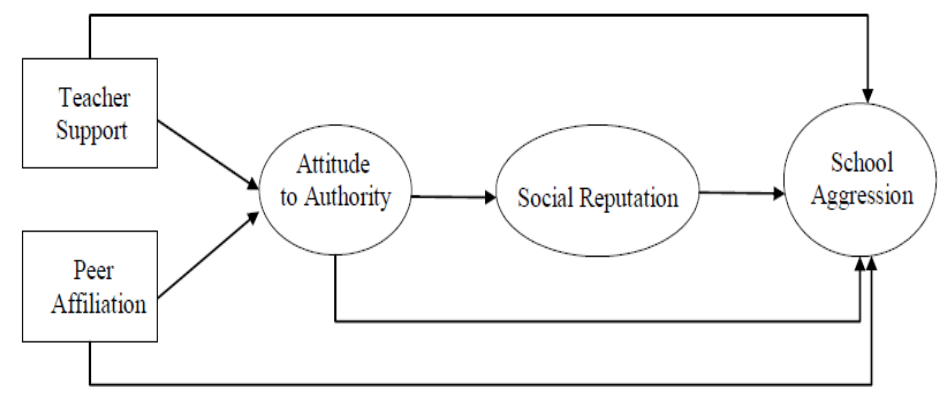

\section{METHOD}

\section{Participants}

Data used in this investigation were gathered from a total sample of 1319 adolescents aged 12-16 (Mean age=13.7, $S D=1.6$ ), 47\% boys and 53\% girls. Participants were drawn from seven state secondary schools in Valencia, a metropolitan area with a population of one million in Spain. The ethnic composition of the sample was predominantly Caucasian and was mostly drawn from intact families of average socioeconomic level. The participants were students of Compulsory Secondary Education and Baccalaureate. Classrooms had an average of 35 students.

\section{Instruments}

Relationship dimension of the Classroom Environment Scale (CES; Moos, Moos and Trickett, 1989). We used two dimensions of this scale, composed of 9 binarychoice (true-false) items: (1) Peer Affiliation, or the extent to which students like and interact positively with each other in the classroom (e.g. "Students in this class get to know each other really well"; "Friendships are made in this class"), and (2) Teacher Support, or the extent of help, encouragement, concern and friendship teacher directs toward students (e.g. "The teacher takes a personal interest in the students", "If the students want to talk about something, the teacher will find time to do it"). Cronbach's alpha coefficients for these subscales in the current study were .79, and .89 respectively.

Attitude to Authority Scale (adapted from Reicher and Emler, 1985). This scale is composed of 10 items and respondents indicate whether they agree or disagree with each statement on a 4-point scale ( 1 = I totally disagree, $4=$ I totally agree"). It was designed to measure student's attitudes towards teachers and school staff as formal authorities. Principal component analysis with varimax rotation revealed a two-factor structure: the first factor (25.74\% of variance) was defined by six items reflecting a positive attitude to school and teachers (e.g. "I agree with what my teachers say and do"; 
"It is okay to disobey teachers if there is no punishment", reverse coded), while the second factor (21.71\% of variance) was defined by four items referring to perception of injustice (e.g. "Teachers only take care of students with good marks"). Cronbach's alpha coefficients for these subscales in the current study were .77 and .73 respectively.

Non-conforming Reputation Scale (Carroll, Hattie, Durkin \& Houghton, 1999). This 15 -item scale assesses the non-conforming social reputation of school-aged children (e.g. "I'm a bully", "I'm a leader", "I'm a tough guy"), responses being given on a four-point scale (1=Never, 4=Always). Students were asked to indicate for the 15 items: (1) their perceived reputation ("My friends think that..."), and (2) their ideal reputation ("I would like my friends to think that...). Cronbach's alpha coefficient for perceived reputation was .85 in the present sample and for ideal reputation was .79 .

Aggressive Behaviour Scale (adapted from Little, Henrich, Jones \& Hawley, 2003). On this scale, participants report how often they have engaged in 24 different aggressive behaviours at school over the last 12 months, on a 4-point scale. Principal component analysis with varimax rotation indicated a three factor structure underlying responses on this scale: the first factor $(31.72 \%$ of variance) was defined by ten items referring to overt aggression (e.g. "I'm the type of person who hits, kicks, or punches others"), the second factor (22.67\% of variance) was defined by seven items referring to relational aggression (e.g. "If others have hurt me, I often try to keep them from being in my group of friends"), and the third factor (19.64\% variance) was defined by seven items referring to instrumental aggression (e.g. "I often start fights to get what I want"). Cronbach's alpha coefficients for these subscales in the current study were $.82, .73$, and .78 respectively.

\section{Procedure}

After pre-contacts were made with several public schools randomly selected in Valencia, seven of them finally agreed to participate in the study based primarily on their availability and the willingness of staff to collaborate in the investigation. Following initial contact with head teachers of each school, all teaching staff was informed of the objectives, importance and implications of the study during a two-hour presentation. Once their collaboration was granted, a letter describing the study was also sent to the parents of students requesting that they indicated in writing if they did not wish their child to participate in (1\% of parents chose this option).

After guaranteeing consent from parents, members of the research team went to schools to collect the data from students who filled in the battery of instruments anonymously and voluntarily, and in their classrooms during a regular class period lasting approximately 45 minutes, under the supervision of a member of the research team. All scales were translated into Spanish using the back-translation procedure. 


\section{RESULTS}

Table 1 shows the correlation matrix with bivariate correlations among observed variables included in the study. This table also gives the means and standard deviations for each variable. This exploratory analysis, conducted as a first approach to examine relationships among variables, showed significant correlations among most of variables of interest and mainly between the three dimensions of aggression considered and the rest of the constructs. Therefore, we proceeded to test the model proposed.

Table 1. Pearson Correlations among Observed Variables, Means and Standard Deviations

\begin{tabular}{|c|c|c|c|c|c|c|c|c|c|}
\hline Variables & 1 & 2 & 3 & 4 & 5 & 6 & 7 & 8 & 9 \\
\hline 1. Teacher Support & - & & & & & & & & \\
\hline 2. Peer Affiliation & $.09 *$ & - & & & & & & & \\
\hline 3. Attitude - Positive Attitude & $.15^{* *}$ & $.12 * *$ & - & & & & & & \\
\hline 4. Attitude - Perception Injustice & $-.19 * *$ & $-.08^{*}$ & $-.39 * *$ & - & & & & & \\
\hline 5. Non-conforming Social Reputation - Perceived & $-.15 * *$ & $-.07 *$ & $-.38 * *$ & $.43 * *$ & - & & & & \\
\hline 6. Non-conforming Social Reputation - Ideal & $-.06^{*}$ & -.04 & $-.28 * *$ & $.33^{* *}$ & $.68 * *$ & - & & & \\
\hline 7. Aggressive Behaviour - Overt & $-.19 * *$ & $-.10 * *$ & $-.28 * *$ & $.34 * *$ & $.45 * *$ & $.31 * *$ & - & & \\
\hline 8. Aggressive Behaviour - Relational & $-.19 * *$ & $-.11 * *$ & $-.30 * *$ & $.34 * *$ & $.41 * *$ & $.32 * *$ & $.60^{* *}$ & - & \\
\hline 9. Aggressive Behaviour - Instrumental & $-.17 * *$ & $-.09 *$ & $-.25 * *$ & $.38 * *$ & $.39 * *$ & $.28 * *$ & $.68 * *$ & $.59 * *$ & - \\
\hline Mean & 13.42 & 16.17 & 15.58 & 12.69 & 11.54 & 10.03 & 12.24 & 14.18 & 13.71 \\
\hline Standard Deviation & 3.14 & 2.07 & 3.87 & 3.01 & 3.96 & 3.73 & 1.88 & 2.67 & 2.34 \\
\hline
\end{tabular}

After standardizing the variables, a measurement model was firstly constructed with the factors included in the model. Table 2 reports the factor loadings of the observed variables on their corresponding latent factors.

Table 2. Unstandardized Parameter Estimates, Standard Errors, and Significance Levels

\begin{tabular}{lcc}
\hline \multicolumn{1}{c}{ Variables } & Factor loadings & Standard errors \\
\hline Teacher Support & $1^{\mathrm{a}}$ & 0 \\
Peer Affiliation & $1^{\mathrm{a}}$ & 0 \\
Attitude to Authority & & \\
Perception of injustice & $.865^{* * *}$ & 0.067 \\
Positive Attitude & $-1^{\mathrm{a}}$ & 0 \\
Non-conforming Social Reputation & & \\
Ideal & $.710^{* * *}$ & 0.038 \\
Perceived & $1^{\mathrm{a}}$ & 0 \\
Aggressive Behaviour & & \\
Relational & $907^{* * *}$ & 0.037 \\
Instrumental & $.909^{* * *}$ & 0.035 \\
Overt & $1^{\mathrm{a}}$ & 0 \\
\hline Robust statistics. ${ }^{\text {a }}$ Fixed to 1.00 during estimation. & \\
&
\end{tabular}

The latent factors included in the structural model were: Teacher Support (indicator: teacher support dimension of the Classroom Environment Scale), Peer Affiliation (indicator: peer affiliation dimension of the Classroom Environment Scale), Positive Attitude to Authority (indicators: positive attitude and perception of injustice subscales of the Attitude to Formal Authority Scale), Non-Conforming Social Reputation 
(indicators: non-conforming perceived and non-conforming ideal reputation of the Nonconforming Reputation Scale), and Aggressive Behaviour (indicators: overt, relational, and instrumental aggression subscales of the Aggressive Behaviour Scale). Because Teacher Support and Peer Affiliation consisted of only one indicator, their factor loadings were 1 with an error 0 .

Secondly, in order to analyse the influence of classroom environment, attitude to formal authority and social reputation among peers on aggressive behaviour at school, a structural equation model was tested using the EQS 6.1 software program (Bentler \& $\mathrm{Wu}, 2002)$. As the authors of the EQS program suggests, because $\chi^{2}$ is very sensitive with large sample sizes, it is recommendable to use several measures of fit. Therefore, the following goodness-of-fit indexes were used: the comparative fit index or CFI, the goodness of fit index or GFI, the Bentler-Bonett's nonnormed fit index or NNFI, and the root mean square error of approximation or RMSEA. Values of CFI, GFI and NNFI above .95 and values of RMSEA below .05 are indicative of a good fit (Batista and Coenders, 2000; $\mathrm{Hu} \&$ Bentler, 1999). Fit indexes obtained for the estimated model in the current study were: $\chi^{2}(24, N=1319)=62.884 \quad(p<.000)$. CFI=.98, GFI=.98, $\mathrm{NNFI}=.97$, and RMSEA=.04. Additionally, we calculated the expected cross-validation index (ECVI) to estimate how well the model fitted in an independent sample. This index measures the discrepancy between the fitted covariance matrix in the analyzed sample and the expected covariance matrix that would be obtained in another sample of equivalent size. Values obtained for the ECVI were .079 in our model and 1.91 in the independent model. This result confirms the model fit, since the smallest ECVI value exhibits the greatest potential for replication. The model proposed accounted for $46 \%$ of the variance in the final variable -aggressive behaviour- with an effect size of .85. This effect size is considered large (Cohen, 1988).

Figure 1 presents the structural model with the standardized path coefficients and their level of significance. As associations depicted in this figure indicated, only an indirect relationship between teacher support and peer affiliation with aggressive behaviour at school was found. This association was established through attitude to authority and non-conforming social reputation. In first place, we observed a direct influence of both teacher support and peer affiliation on students' positive attitude to authority $(\beta=.26, p<.001$ and $\beta=.13, p<.001$ respectively). In second place, results revealed attitude to authority to be strongly related to non-conforming social reputation ( $\beta=-.66, p<.001)$ which, in turn, showed a significant association with aggressive behaviour $(\beta=.22, p<.001)$. Moreover, the model showed a direct significant and negative path from positive attitude to authority to aggressive behaviour $(\beta=-.52$, $p<.001)$. Thus, only an indirect relation between school environment and aggression was found when attitude to authority and social reputation were included in the model, both of which were in turn directly related to school aggression. 
Figure 2. Standardized solution of the structural model

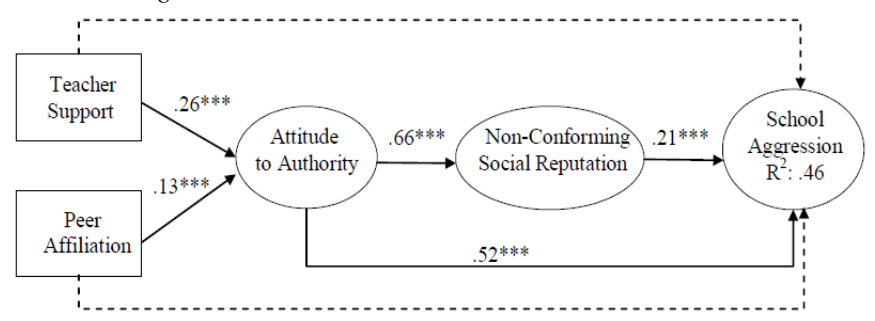

We checked the robustness of this model further by testing structural invariance across gender groups through multigroup analyses (Bentler \& Wu, 2002). Two models were tested: in the unrestricted model, parameter estimates (factor loadings and structural paths) were freely estimated across groups; in the restricted model, we constrained each of the factor loadings as well as the structural paths to be invariant across groups. If the $\chi^{2}$ of the restricted model was significantly larger than the $\chi^{2}$ of the unrestricted model, the assumption of invariance would not be tenable. Results indicated a non-significant difference between these models for boys and girls: $\chi^{2}(21, N=1319)=18.948, \mathrm{~ns}$; this result supported, therefore, invariance of the general model across gender groups.

\section{DISCUSSION}

The focus of this study was to analyse the role played by attitude to school and social reputation among peers in the relationship between classroom environment and involvement in aggressive acts in the school setting. Classroom environment was defined by two dimensions referring to perception of a supportive relation with teachers and affiliation among classmates. As expected, our findings revealed an indirect association between classroom environment and school aggression; attitude to authority and social reputation were shown as significant connectors in this relationship. This result suggests that quality of interactions with teachers and classmates are important influences on students' behaviour, as other authors have remarked (Blankemeyer et al., 2002; García \& Orellana, 2008; Reinke \& Herman, 2002), but also that this effect is more likely when negative social interactions in turn influence relevant individual orientations towards the social world, such as certain attitudes and wishes regarding others. This result help us to understand the process by which classroom environment affects the development of misbehaviours, indicating that this association is explained, at least in part, by the attitude the student develops towards the school itself and the teacher staff (as formal authorities), as well as by the particular social reputation to which they aspire, namely as non-conforming and rebellious individuals. 
Firstly, we observed in the data that the extent to which students feel liked by their classmates and interact positively with others in the classroom, as well as the extent of help, support, trust and concern they perceive from the teacher, are both influential factors in the development of their attitudes towards the school context. This finding suggests that perceived social support in the educational setting may be one of the most relevant aspects in students' consideration of school as a useful context and educators as valued authority figures, with the subsequent beneficial consequences this may entail for coexistence in schools. Our result is also in line with those reported by Molpeceres et al. (2000) stressing the importance of school experience in the shape of perceptions regarding formal authority figures and institutions, and consistent with conclusions from studies conducted by Demaray and Malecki (2002), and Taylor and Nelms (2006), who point out the positive effects of peer friendships and quality interactions with teachers in engagement with the school.

Secondly, data revealed that attitude to authority and preference for a nonconforming social reputation, contributed in the final model to the explanation of the link between classroom environment and aggressive behaviour. Specifically, what our results suggested is that students displaying a positive attitude towards school and teachers are less likely to be involved in the search of a social reputation based on rebelliousness and indiscipline, which in turn enhances the likelihood of students' involvement in aggressive acts. From this perspective and according to Emler (1984), distrust in the authority (versus perception of safety and protection) may lead to establishment of a particular social identity and reputation in accord with the values defended by the individual, that in the case of adolescents sharing the characteristics mentioned, is frequently related to rejection of socially sanctioned values and, thus, to consequent involvement in antisocial and aggressive acts (see also Carroll et al., 2003; Emler \& Reicher, 2005). Thus, the expression of aggressiveness at school may be reflecting the need to establish and maintain a social identity and gain recognition, along with the message of disapproval of formal authority.

Finally, we also found a strong direct link between attitude to authority and aggressive behaviour on the part of students. More concretely, we observed that a positive attitude to school and teachers is itself a protective factor in this sense. This result is in line with those reported by Levy (2001) and by Tarry and Emler (2007), both indicating high negative correlations between youths' attitude to formal authority and involvement in offending behaviours. Previous researches have emphasised the other side of the coin: adolescents who show antisocial and aggressive behaviours express more negative attitudes towards formal figures and institutions, such as teachers and the school context (Adair et al., 2000; Emler \& Reicher, 1995, 2005; Hoge, Andrews \& Lescheid, 1996; Loeber, 1996). 
In conclusion, with respect to aggressive behaviour the current research contributes to our understanding of the influence process deriving from the classroom social environment. To this end, we jointly analysed relationships among these factors and others previously identified in the research literature, namely attitude to school and social reputation among peers, showing that both play an important role. These findings have some relevant practical implications. First of all, it is important to highlight that interventions should not only focus on the particular individuals involved; such decision would be overlooking relevant contextual factors that need to be taken into consideration to understand and mitigate the problem. Intervention programs that improve commitment to school and attitudes to teachers and educational centres would be very useful, as it would be also empowerment to students to seek and benefit from positive identities, instead of bad reputations.

It is also desirable for teacher education programs to give serious consideration to the relevance of democratic practices in the classroom that promote the feeling of belonging and support, as well as the establishment of cooperation relations among all the individuals sharing the same learning context; setting up these practices would improve students' general attitudes to the institution and would probably reduce unruly behaviours, thereby moving a step closer to avoiding the appearance of new misbehaviours at school. Along this line and in accordance with the intervention program developed by Mooij (1999), social-pedagogical and didactic classroom characteristics are crucial for the development of prosocial and cooperative behaviours of students. Having said that, we acknowledge the following limitations. The use of selfreported data may create vulnerability to response bias that could impact the validity and generalizability of the findings. However, as various authors indicate, the reliability and validity of adolescents' self-reports when measuring risk behaviours such as offending and aggressive behaviour is acceptable (Flisher, Evans, Muller \& Lombard, 2004; Ritakallio, Kaltiala-Heino, Kivivuori \& Rimpelä, 2005). It should also be noted that as the present study used a cross-sectional design based on correlational analyses, one should be cautious about making causal inferences. Thus, some bidirectional relationships among the study variables are plausible, as in the case of the attitudebehaviour link (Holland, Verplanken \& van Knippenberg, 2002): antisocial behaviours are normally sustained by negative prejudices about formal authority, but likewise existing habits of behaviour may shape the individual's attitude towards authority (Emler \& Reicher, 2005; Nihart, Lersch, Sellers \& Mieczkowski, 2005). Finally, the authors also acknowledge the limited generalizability of the model obtained; further research needs to be conducted on other populations in which the school context may have different meanings and implications for students. To sum up, we believe that findings of the current study may guide future research that analyses the relations examined herein in more depth, thus contributing to improving our understanding of the problem of 
aggression in schools. A longitudinal study would also be desirable to clarify causal relationships and bidirectional associations among variables.

\section{REFERENCES}

Adair, V.A., Dixon, R.S., Moore, D.W. \& Sutherland, C.M. (2000). Bullying in New Zealand secondary schools. New Zealand Journal of Educational Studies, 35, 207-221.

Andreou, E. (2000). Bully/Victim problems and their association with psychological constructs in 8-to 12-year old Greek schoolchildren. Aggressive Behavior, 26, 49-56.

Barnow, S., Lucht, M. \& Freyberger, H.J. (2005). Correlates of aggressive and delinquent conduct problems in adolescence. Aggressive Behavior, 31, 24-39.

Batista, J.M. \& Coenders, G. (2000). Modelos de ecuaciones estructurales [Structural Equation Models]. Madrid: La Muralla.

Barry, M. (2006). Youth offending in transition: the search for social recognition. London: Routledge.

Bentler, P. \& Wu, E. (2002). EQS 6 for windows user's guide. Encino, CA: Multivariate Software.

Blankemeyer, M., Flannery, D.J. \& Vazsonyi, A.T. (2002). The role of aggression and social competence in children's perceptions of the child-teacher relationship. Psychology in the Schools, 39, 293-304.

Browne, M.W. \& Cudek, R. (1993). Alternative ways of assessing model fit. In K. Bollen \& J. S. Long (Eds.), Testing structural equation models (pp. 136-162). London: SAGE.

Buelga, S., Musitu, G., Murgui, S. \& Pons, J. (2008). Reputation, loneliness, satisfaction with life and aggressive behavior in adolescence. The Spanish Journal of Psychology, 11, 192200.

Carrasco, C. \& Trianes, M. V. (2010). Clima social, prosocialidad y violencia como predictores de inadaptación escolar en primaria. European Journal of Education and Psychology, 3, 229-242.

Carroll, A., Green, S., Houghton, S. \& Wood, R. (2003). Reputation enhancement and involvement in delinquency among high school students. International Journal of Disability, Development and Education, 50, 253-273.

Carroll, A., Hattie, J., Durkin, K. \& Houghton, S. (1999). Adolescent reputation enhancement: differentiating delinquent, nondelinquent, and at-risk youths. Journal of Child Psychology and Psychiatry, 40, 593-606.

Cohen, J. (1988). Statistical Power Analysis for the Behavioral Sciences. Hillsdale, NJ: Erlbaum.

Demaray, M. P. \& Malecki, C. K. (2002). The relationship between perceived social support and maladjustment for students at risk. Psychology in the Schools, 39, 305-316.

Demaray, M.P., Malecki, C.K., Davidson, L., Hogdson, K. \& Rebus, P. (2005). The relationship between social support and student adjustment: A longitudinal analysis. Psychology in the Schools, 42, 691-706.

Dishion T.J. (2000). Cross-setting consistency in early adolescent psychopathology: deviant friendships and problem behavior sequelae. Journal of Personality, 68, 1109-1126.

Emler, N. (1984). Differential involvement in delinquency: Toward an interpretation in terms of reputation management. In B. A. Maher and W. B. Maher (Eds.), Progress in experimental personality research (pp. 173-237). New York: Academic Press.

Emler, N. (2009). Delinquents as a minority group: Accidental tourist in forbidden territory or voluntary émigrés? In F. Butera \& J. Levine (Eds.), Coping with minority status: Responses to exclusion and inclusion. Cambridge: Cambridge University Press.

Emler, N. and Reicher, S. (1995). Adolescence and delinquency. Oxford: Blackwell. 
Emler, N. and Reicher, S. (2005). Delinquency: cause or consequence of social exclusion? In D. Abrams, J. Marques and M. Hogg (Eds). The social psychology of inclusion and exclusion. (pp. 211-241). Philadelphia: Psychology Press.

Estévez, E., Herrero, J., Martínez, B. \& Musitu, G. (2006). Aggressive and non-aggressive rejected students: an analysis of their differences. Psychology in the Schools, 43, 387-400.

Estévez, E., Murgui, S. \& Musitu, G. (2008). Psychosocial adjustment in aggressors, pure victims and aggressive victims at school. European Journal of Education and Psychology, 1, 2939.

Estévez, E., Musitu, G. \& Herrero, J. (2005). The influence of violent behavior and victimization at school on psychological distress: the role of parents and teachers. Adolescence, 40, 183-195.

Flisher, A. J., Evans, J., Muller, M. \& Lombard, C. (2004). Brief report: Test-retest reliability of self-reported adolescent risk behaviour. Journal of Adolescence, 27, 207-212.

García, J. \& Orellana, M.C. (2008). Variables psicológicas moduladoras de la autodefinición del perfil en procesos de acoso escolar: el papel del género y el curriculum escolar. European Journal of Education and Psychology, 1, 41-55.

Hartup, W.W. (1996). The company they keep: Friendships and their developmental significance. Child Development, 67, 1-13.

Hoge, R.D., Andrews, D.A. \& Leschied, A.W. (1996). An investigation of risk and protective factors in a sample of youthful offenders. Journal of Child Psychology and Psychiatry ad Allied Discplines, 37, 419-424.

Holland, R.W., Verplanken, B. \& van Knippenberg, A. (2002). On the nature of attitude-behavior relations: the strong guide, the weak follow. European Journal of Social Psychology, 32, 869-876.

Hu, L. \& Bentler, P. (1999). Cut-off criterion for fit indexes in covariance structure analysis: Conventional criteria versus new alternatives. Structural Equation Modeling, 6, 1-55.

Hunter, S.C., Mora-Merchán, J. \& Ortega, R. (2004). The long-term effects of coping strategy use in victims of bullying. The Spanish Journal of Psychology, 7, 3-12.

Inglés, C.J. (2009). Programa PEHIA. Enseñanza de habilidades interpersonales para adolescentes. $3^{\mathrm{a}}$ Ed. Madrid: Pirámide.

Jack, S.L., Shores, R.E., Denny, R.K., Gunter, P.L., DeBriere, T. \& DePaepe, P. (1996). An analysis of the relationships of teachers' reported use of classroom management strategies on types of classroom interactions. The Journal of Behavioral Education, 6, 67-87.

Laursen, B. (1995). Conflict and social interaction in adolescent relationships. Journal of Research on Adolescence, 5, 55-70.

Lawrence, C. \& Green, K. (2005). Perceiving classroom aggression: The influence of setting, intervention style and group perceptions. British Journal of Educational Psychology, 75, 587-602.

Levy, K.S. (2001). The relationship between adolescent attitudes towards authority, self-concept, and delinquency. Adolescence, 36, 333-346.

Little, T.D., Henrich, C.C., Jones, S.M. \& Hawley, P.H. (2003). Disentangling the "whys" from the "whats" of aggressive behaviour. International Journal of Behavioral Development, 27, 122-133.

Loeber, R. (1996). Developmental continuity, change and pathways in male juvenile problem behaviours and delinquency. In J. D. Hawkins (Ed.), Delinquency and crime: current theories (pp. 28-67). New York: Cambridge University Press. 
Molpeceres, M.A., Lucas, A. \& Pons, D. (2000) Experiencia escolar y orientación hacia la autoridad institucional en la adolescencia [School experience and orientation towards institutional authority in adolescence]. Revista de Psicología Social, 15, 87-105.

Mooij, T. (1999). Promoting prosocial pupil behaviour: 2-secondary school intervention and pupil effects. British Journal of Educational Psychology, 65, 479-504.

Moos, R.H. (1974). The Social Climate Scales: An Overview. Palo Alto, CA: Consulting Psychologists Press.

Moos, R.H., Moos, B.S. \& Trickett, E.J. (1989). FES, WES, CIES, CES. Escalas de Clima Social [Social Environment Scales]. Madrid: TEA.

Moote, G.T., Jr. \& Wodarski, J.S. (1997). The acquisition of life skills through adventure-based activities and programs: A review of the literature. Adolescence, 32, 143-167.

Murray, C. \& Murray, K.M. (2004). Child level correlations of teacher-students relationships: an examination of demographic orientation characteristics, academia orientations, and behavioral orientations. Psychology in the Schools, 41, 751-762.

Peterson, R.L. \& Skiba, R. (2000). Creating school climates that prevent school violence. Preventing School Failure, 44, 122-129.

Reicher, S. \& Emler, N. (1985). Delinquent behavior and attitudes to formal authority. British Journal of Social Psychology, 3, 161-168.

Reinke, W.M. \& Herman, K.C. (2002). Creating school environment that deter antisocial behaviors in youth. Psychology in the Schools, 39, 549-559.

Ritakallio, M., Kaltiala-Heino, R., Kivivuori, J. and Rimpelä, M. (2005). Brief report: Delinquent behaviour and depression in middle adolescence: a Finnish community sample. Journal of Adolescence, 28, 155-159.

Rodríguez, N. (2004). Guerra en las aulas [War in the classrooms]. Madrid: Temas de Hoy.

Samdal, O. (1998). The school environment as a risk or resource for students' health-related behaviors and subjective well-being. Norway: Research Centre for Health Promotion, University of Bergen.

Smith, P.K. \& Brain, P. (2000). Bullying in schools: lessons from two decades of research. Aggressive Behavior, 26, 1-9.

Sprague, J., Walker, H., Stieber, S., Simonsen, B., Nishioka, V. \& Wagner, L. (2001). Exploring the relationship between school discipline referrals and delinquency. Psychology in the Schools, 38, 197-206.

Tarry, H. \& Emler, N. (2007). Attitudes, values and moral reasoning as predictors of delinquency. British Journal of Developmental Psychology. 25, 169-183.

Taylor, J. \& Nelms, L. (2006). School engagement and life changes. Fitzroy: Brotherhood of St Laurence.

Torregrosa, M.S., Inglés, C.J., García-Fernández, J.M., Gázquez, J.J., Díaz-Herrero, A. \& Bermejo, R.M. (2012). Conducta agresiva entre iguales y rendimiento académico en adolescentes españoles. Behavioral Psychology/Psicología Conductual, 20(2), 263-280.

Trickett, E.J., Leone, P.E., Fink, C.M. \& Braaten, S.L. (1993). The perceived environment of special education classrooms for adolescents: A revision of the classroom environment scale. Exceptional children, 59, 441-420.

Yoneyama, S. \& Rigby, K. (2006). Bully/victim students and classroom climate. Youth Studies Australia, 25, 34-41.

Received: February 15th, 2013

Modifications Received: March 8th, 2013

Accepted: March 15th, 2013 